\title{
Pentingnya Pengetahuan Pasien Dan Keluarga Tentang Mencegah Terjadinya Bahaya Dan Adverse Events Di Rumah Sakit
}

\author{
Putri Meiyarny Zega \\ putrimeiyarny@gmail.com
}

\section{LATAR BELAKANG}

Keselamatan Pasien (Patient Safety) merupakan sesuatu yang jauh lebih penting dari pada sekedar efisiensi pelayanan. Perilaku perawat dengan kemampuan perawat sangat berperan penting dalam pelaksanaan keselamatan pasien. Perilaku yang tidak aman, lupa, kurangnya perhatian/motivasi, kecerobohan, tidak teliti dan kemampuan yang tidak memperdulikan dan menjaga keselamatan pasien berisiko untuk terjadinya kesalahan dan akan mengakibatkan cedera pada pasien, berupa Near Miss (Kejadian Nyaris Cedera/KNC) atau Adverse Event (Kejadian Tidak Diharapkan/KTD) selanjutnya pengurangan kesalahan dapat dicapai dengan memodifikasi perilaku. Perawat harus melibatkan kognitif, afektif dan tindakan yang mengutamakan keselamatan pasien.

Keluarga merupakan unit paling dekat dengan pasien, dan merupakan perawat utama bagi pasien. Keluarga berperan dalam menentukan cara atau perawatan yang diperlukan pasien di rumah sakit. Keberhasilan perawat di rumah sakit akan sia-sia jika tidak diteruskan di rumah yang kemudian mengakibatkan pasien harus dirawat kembali (kambuh). Peran serta keluarga sejak awal perawatan di rumah sakit akan meningkatkan kemampuan keluarga merawat pasien di rumah sehingga memungkinkan pasien tidak kambuh atau dapat dicegah.

Keluarga merupakan bagian dari tim pengobatan dan perawatan. Apalagi di Indonesia dengan kultur sosialnya tinggi ditambah keterbatasan jumlah perawat di rumah sakit sehingga tugas merawat orang sakit yang dirawat di rumah sakit umumnya dilakukan oleh keluarga yang menjaga. Para anggota keluarga menunggui secara bergantian, bahkan sering menjaga bersama-sama. Sementara perawat di rumah sakit yang seharusnya merawat orang sakit juga harus melakukan tugas-tugas yang lain di bangsal perawatan. Maka, peran keluarga penting untuk memantau kebutuhan pasien dari laporan perawat atau jika perlu malakukan komunikasi langsung.

METODE 
Artikel ilmiah ini dibuat dengan menggunakan metode literasi/membaca dan menganalisa kajian dari berbagai sumber atau referensi terkait seperti jurnal, buku teks, dan Ebook 8 tahun terakhir. Artikel ilmiah ini ditulis dengan mengacu pada sumber-sumber terkait yang berfokus pada pengetahuan pasien dan keluarga tentang mencegah terjadinya bahaya dan adverse events.

\section{HASIL}

Hasil analisa yang di dapatkan adalah sebuah survei yang dilakukan di rumah sakit Amerika Serikat mengenai praktek pasien dan keterlibatan pasien dan keluarga pasien dalam mengelola pasien di rumah sakit menunjukkan hal yang luar biasa. Hasilnya pasien dan keluarga pasien yang dilibatkan dalam pengambilan keputusan secara bersama-sama dalam perawatan dan menjadikan pasien sebagai mitra dapat meningkatkan optimalisasi kesembuhan pasien, selain itu dengan melibatkan anggota keluarga seperti berpartisipasi dalam koordinasi keperawatan sangat penting..

Beberapa rumah sakit mengizinkan pasien untuk membawa alat komunikasi yang perlu digunakan. Hal ini juga terbukti dari hasil penelitian yang dilakukan di rumah sakit Amerika serikat bahwa dengan keterlibatan pasien maupun anggota keluarganya dalam merawat dan memberikan kesempatan kepada keluarga pasien untuk berkunjung ke rumah sakit lebih lama dapat menguragi resiko kecemasan yang berlebihan yang diderita oleh pasien. Tentunya hal ini dapat dirasakan jika penderita merasakan adanya dukungan sosial dari orang-orang sekitarnya, merasa dirinya dihargai, diperhatikan dan dicintai.

Contohnya adalah bila ada seseorang yang sakit dan terpaksa di rawat di rumah sakiy maka sanak saudara ataupun teman-teman biasanya datang berkunjung. Dengan kunjungan tersebut maka orang yang sakit atau pasien ini tentu merasa mendapat dukungan sosial sehingga secara tidak langsung dapat mempercepat kesembuhan.

Keluarga yang akan menerima penderita di rumah sepulang dari rumah sakit. Begitu siap dipulangkan keluarga menerima estafet pengelolaan penderita di rumah sebagai kelanjutan pengelolaan di rumah sakit. Karena itu selama di rumah sakit keluarga berhak atas informasi pengobatan, perawatan, dan penanganan lainnya terhadap penderita. Karena itu bertanya kepada pihak rumah sakit merupakan hak keluarga untuk memperoleh informasi tersebut. Keluarga perlu perlu mulai membuka dan menjalin 'kedekatan' dengan personel rumah sakit untuk keperluan ini. 
Adverse Event atau Kejadian Tidak Diharapkan (KTD) merupakan suatu kejadian yang mengakibatkan cedera yang tidak diharapkan pada pasien karena suatu tindakan (commission) atau tidak mengambil tindakan yang seharusnya diambil (omission), dan bukan karena "underlying disease" atau kondisi pasien.

\section{PEMBAHASAN}

Pasien yang dirawat di rumah sakit merupakan individu yang sedang memiliki masalah kesehatan, sehingga dimungkinkan mengalami kesulitan memenuhi kebutuhan pribadi termasuk menjaga keselamatan senadiri, oleh sebab itu pasien membutuhkan dukungan dari keluarga dan tim kesehatan yang merawat.

Rumah Sakit dalam upaya memberikan pelayanan kesehatan melibatkan tim kerja dari berbagai profesi, maka rumah sakit menyiapkan sistem layanan terintegrasi yang berfokus pada pasien untuk memberi pelayanan yang aman.dengan enam sasaran keselamatan pasien yaitu :

1. Ketepatan identifikasi pasien

2. Komunikasi efektif

3. Pemberian obat secara aman

4. Ketepatan pasien, lokasi dan prosedur operasi

5. Pencegahan infeksi

6. Pencegahan pasien jatuh.

Dalam melaksanakan program tersebut diperlukan kerja sama antara tim kesehatan serta pasien dan keluarga. Peran keluarga secara aktif dalam menjaga keselamatan pasien rawat inap adalah :

1. Memberikan informasi yang benar, jelas, lengkap dan jujur.

2. Mengetahui dan melaksanakan kewajiban serta tanggung jawab pasien maupun keluarga.

3. Mengajukan pertanyaan-pertanyaan untuk hal yang tidak dimengerti.

4. Memahami dan menerima konsekuensi pelayanan.

5. Mematuhi dan menghormati peraturan rumah sakit.

6. Memperlihatkan sikap menghormati dan tenggang rasa dalam proses bersama tim kesehatan mengelola pasien.

7. Memenuhi kewajiban finansial yang disepakati.

Penerapan enam sasaran keselamatan pasien dan peran keluarga dalam menjaga keselamatan pasien rawat inap di rumah sakit 


\section{Ketepatan Identifikasi Pasien}

Pasien dalam keadaan tidak sadar, gelisah, mengalami gangguan penglihatan, gangguan pendengaran, gangguan proses pikir, mendapat obat bius, atau gangguan lain tidak mampu melakukan identifikasi diri dengan benar selain itu pasien yang pindah ruang rawat atau bertukar tempat tidur saat perawatan di rumah sakit berisiko mengalami ketidaktepatan identifikasi, maka rumah sakit menyusun sistem untuk memastikan identifikasi pasien sebagai individu yang akan menerima pelayanan adalah tepat dan jenis pelayanan atau pengobatan terhadap individu tersebut adalah sesuai.

Peran Pasien dan keluarga untuk memastikan ketepatan identifikasi pasien adalah :

a. Memberikan data diri yang tepat pada saat mendaftar sesuai dokumen data diri yang dimiliki. Data utama yang diperlukan adalah nama dan tanggal lahir

b. Selama rawat inap pasien dipakaikan gelang. Pasien dan keluarga harus memahami fungsi gelang dan patuh menggunakan gelang tersebut selama rawat inap karena gelang tersebut dipakai oleh tim kesehatan guna memastikan kebenaran identitas dan faktor risiko pasien saat memberikan pelayanan.

* Gelang warna biru untuk laki-laki dan gelang warna merah muda untuk perempuan dipakai untuk identifikasi

* Gelang warna merah dipasangkan pada pasien yang memiliki riwayat alergi

* Gelang warna kuning dipasangkan pada pasien yang memiliki risiko jatuh

c. Pasien atau keluarga kooperatif saat dilakukan verifikasi identitas oleh petugas saat akan melakukan tindakan, memberikan obat, mengambil preparat untuk pemeriksaan laboratorium dan lain-lain.

\section{Komunikasi Efektif}

Pasien yang menjalani rawat inap dikelola oleh dokter dan berbagai profesi lain sebagai tim dengan menerapkan sistem komunikasi yang efektif untuk memberikan pelayanan. Peran pasien dan keluarga mewujudkan komunikasi efektif adalah :

a. Menunjuk atau menetapkan anggota keluarga yang diberi kewenangan untuk berkomunikasi dengan tim kesehatan. Penunjukkan ini diperlukan untuk memastikan komunikasi berlangsung efektif dan berkesinambungan, tidak mengalami rantai komunikasi yang panjang dan kompleks yang berisiko menyebabkan perubahan makna isi informasi.

b. Memberikan informasi dan data terkait kondisi pasien kepada tim kesehatan dengan benar dan jelas.

c. Memberikan informasi pada petugas bila ada kejadian tidak diharapkan. 
d. Meminta informasi yang diperlukan kepada tim kesehatan

\section{Pemberian Obat Secara Aman}

Pemberian obat merupakan bagian yang mengambil porsi dominan dalam tata kelola pasien rawat inap. Peran serta keluarga dalam menjamin keamanan pemberian obat adalah :

a. Memberikan informasi yang lengkap tentang riwayat obat yang pernah dipergunakan sebelum masuk rumah sakit.

b. Memberikan informasi tentang riwayat alergi atau reaksi yang dialami saat menggunakan obat tertentu.

c. Mendukung pengawasan pemberian obat selama rawat inap dengan cara memastikan identitas pasien benar, menanyakan jenis obat yang diberikan, tujuan pemberian, dosis dan waktu pemberian obat.

\section{Kepastian Tepat-Lokasi, Tepat-Prosedur, Tepat-Pasien Operasi}

Tindakan operasi merupakan salah satu prosedur yang mungkin dilakukan pada pasien untuk mengatasi masalah kesehatannya. Bagian tubuh yang akan dioperasi bisa meliputi bagian yang bersisi (misalnya tangan atau kaki kanan dan kiri, mata kanan dan kiri) atau bagian yang multipel level (misalnya tulang belakang) atau bagian yang multipel struktur (misalnya jari tangan) dengan demikian diterapkan sistem untuk memastikan tindakan tepat-lokasi, tepatprosedur, tepat-pasien.

Salah satu prosedur yang dilakukan sebelum tindakan operasi adalah proses verifikasi. Peran pasien dan keluarga dalam proses verifikasi praoperasi adalah memberikan informasi yang benar dan bekerja sama secara kooperatif. Proses yang dilakukan meliputi :

a. Verifikasi lokasi, prosedur, dan pasien yang benar.

Proses ini dilakukan dengan membuat tanda pada lokasi yang dioperasi. Penandaan lokasi operasi ini melibatkan pasien, dibuat oleh dokter yang akan melakukan tindakan dan dilaksanakan saat pasien dalam keadaan sadar. Tanda ini tidak boleh dihapus dan harus terlihat sampai saat akan disayat.

b. Memastikan bahwa semua dokumen, foto (imaging), hasil pemeriksaan yang relevan tersedia, diberi label dengan baik.

c. Melakukan verifikasi ketersediaan peralatan khusus yang dibutuhkan.

\section{Pengurangan Risiko Infeksi Terkait Pelayanan Kesehatan}

Rumah sakit merupakan tempat yang memungkinkan berkumpulnya berbagai jenis kuman sedangkan pasien yang sedang dirawat memiliki daya tahan tubuh relatif rendah dengan demikian diperlukan suatu proses bersama untuk mencegah timbulnya infeksi lain yang tidak berhubungan dengan penyakit utama pasien. 
Peran pasien dan keluarga dalam pengurangan risiko terkait pelayanan kesehatan adalah

a. Menerapkan prosedur cuci tangan yang benar

Keluarga memiliki kemungkinan sering kontak dengan pasien, maka untuk melindungi diri sendiri dan melindungi pasien dari perpindahan kuman disarankan keluarga menerapkan prosedur cuci tangan yang benar pada 5 (lima) momen yaitu saat sebelum kontak dengan pasien, sesudah kontak pasien, sesudah ke toilet, sebelum dan sesudah makan. Perlu diperhatikan juga bahwa lingkungan sekitar pasien berisiko terpapar kuman maka disarankan mencuci tangan sesudah kontak dengan lingkungan pasien (meja, alat tenun, tempat tidur dsb). Guna memperoleh hasil cuci tangan yang optimal, pasien dan keluarga disarankan mencermati dan mengikuti petunjuk 6 (enam) langkah mencuci tangan yang diberikan oleh petugas atau panduan cuci tangan yang ada di rumah sakit.

b. Membatasi pengunjung pasien

Selama pasien dirawat di rumah sakit seyogyanya pasien tidak berinteraksi dengan banyak orang karena berisiko terpapar kuman dari pengunjung dalam keadaan pertahanan diri yang relatif rendah dengan demikian peran keluarga diperlukan untuk membatasi pengunjung yang kontak dengan pasien.

c. Menerapkan etika batuk yang benar

Keluarga dan pengunjung yang batuk berisiko menyebarkan kuman melalui partikel halus di udara dengan demikian bila sedang mengalami batuk keluarga perlu menggunakan masker atau menerapkan tehnik perlindungan yang benar saat batuk yaitu menutup mulut dan hidung menggunakan lengan.

\section{Pengurangan Risiko Pasien Jatuh}

Individu yang sedang sakit memiliki keterbatasan dalam pengamanan diri termasuk menghindari jatuh. Rumah sakit mengambil tindakan untuk mengurangi risiko dengan melakukan pengkajian faktor-faktor yang dapat menyebabkan jatuh seperti, penggunaan obat, gaya jalan dan keseimbangan, alat bantu berjalan yang digunakan oleh pasien, riwayat jatuh saat berjalan atau saat istirahat baring di tempat tidur.

Peran pasien dan keluarga dalam mencegah jatuh saat dirawat di rumah sakit adalah : pastikan penanda pasien beresiko jatuh berupa gelang kuning dipakai pasien. Jangan melepas atau memindah kartu kuning yang dipasang petugas dekat tempat tidur pasien atau di depan kamar pasien karena kartu tersebut merupakan penanda untuk mewaspadai pasien yang 
beresiko jatuh. Keluarga atau pasien perlu memastikan diri untuk memahami informasi yang diberikan oleh petugas agar dapat mendukung tindakan pencegahan jatuh.

Informasi yang perlu diketahui adalah :

a. faktor resiko jatuh yang teridentifikasi seperti obat yang dipergunakan, kesadaran pasien, keseimbangan saat berjalan, dll.

b. tindakan pencegahan jatuh yang perlu dilakukan

c. cara untuk minta bantuan

d. cara menggunakan bel atau sarana komunikasi di ruangan

e. cara mengatur pengamanan tempat tidur

f. pengggunaan tali pengaman, dll.

Adverse Event atau Kejadian Tidak Diharapkan (KTD) merupakan suatu kejadian yang mengakibatkan cedera yang tidak diharapkan pada pasien karena suatu tindakan (commission) atau tidak mengambil tindakan yang seharusnya diambil (omission), dan bukan karena "underlying disease" atau kondisi pasien.

Kesalahan tersebut bisa terjadi dalam tahap diagnostic seperti kesalahan atau keterlambatan diagnose, tidak menerapkan pemeriksaan yang sesuai, menggunakan cara pemeriksaan yang sudah tidak dipakai atau tidak bertindak atas hasil pemeriksaan atau observasi; tahap pengobatan seperti kesalahan pada prosedur pengobatan, pelaksanaan terapi, metode penggunaan obat, dan keterlambatan merespon hasil pemeriksaan asuhan yang tidak layak; tahap preventive seperti tidak memberikan terapi provilaktik serta monitor dan follow up yang tidak adekuat; atau pada hal teknis yang lain seperti kegagalan berkomunikasi, kegagalan alat atau system yang lain.

\section{PENUTUP}

\section{Kesimpulan}

Keluarga merupakan unit paling dekat dengan pasien, dan merupakan perawat utama bagi pasien. Keluarga berperan dalam menentukan cara atau perawatan yang diperlukan pasien di rumah sakit. Keberhasilan perawat di rumah sakit akan sia-sia jika tidak diteruskan di rumah yang kemudian mengakibatkan pasien harus dirawat kembali (kambuh). Peran serta keluarga sejak awal perawatan di rumah sakit akan meningkatkan kemampuan keluarga merawat pasien di rumah sehingga memungkinkan pasien tidak kambuh atau dapat dicegah. 
Pengelolaan pasien rawat inap tidak hanya mejadi tanggung jawab tim kesehatan tetapi melibatkan juga pribadi pasien sendiri dan keluarga, maka setiap bagian perlu menjalankan peran masing-masing sesuai tugasnya karena proses kerja sama yang baik merupakan dasar yang kuat untuk memperoleh hasil optimal.

2. Saran

Sebagai seorang perawat ataupun mahasiswa keperawatan dapat berkerja profesional dalam menjalankan tugas dan kewajiban sebagai seorang perawat yang ideal dan bertanggung jawab. Perawat/petugas melakukan pekerjaan sesuai standar prosedur operasional (SPO) yang ada dengan baik dan benar, dapat bekerja dengan hati-hati, fokus, dan selalu mengutamakan K3 (Keselamatan dan Kesehatan Kerja) dalam bekerja. Dan juga diharapkan agar pasien dan keluarga mempunyai pengetahuan dan peran untuk mencegah bahaya dan adverse event.

\section{DAFTAR PUSTAKA}

Agnes Ferusge, A. B. (2018). Faktor yang Mempengaruhi Tindakan Keselamatan Radiasi Sinar-X di Unit Radiologi Rumah Sakit Putri Hijau Medan. Journal of Borneo Holistic Health, 1(2), 264-270.

Bostwick, A. D and Beesley, S. J. (2018). Family Role in Patient Safety in the Intensive Care Unit : A Guide to Understanding, Engaging, and Supporting at the Bedside. Families in the Intensive Care Unit, 277-287.

Cahyono, Agung. (2015). Hubungan Karakteristik dan Tingkat Pengetahuan Perawat Terhadap Pengelolaan Keselamatan Pasien di Rumah Sakit. Jurnal Ilmiah Widya, 3(2), 97-102.

Collier, A., Sorensen, A., and Idema, R. (2016). Patients' and families' perspectives of patient safety at the end of life: a video-reflexive ethnography study. International Journal for Quality in Health Care, 28 (1), 66-73.

Herawati,Y, T. (2015). Budaya Keselamatan Pasien. Jurnal IKESMA, 11(1), 52-60.

Ismainar, H. (2019). Keselamatan Pasien di Rumah Sakit. Yogyakarta: Deepublish.

Kementerian Kesehatan Republik Indonesia. (2016). Peraturan Menteri Kesehatan Republik Indonesia Nomor 66 Tahun 2016 tentang Keselamatan dan Kesehatan Kerja Rumah Sakit. Jakarta : Kementerian Kesehatan RI. 
Lombogia, Angelita, Julia Rottie, Michael Karundeng. 2016). Hubungan Perilaku Dengan Kemampuan Perawat Dalam Melaksanakan Keselamatan Pasien (Patient Safety) Di Ruang Akut Instalasi Gawat Darurat Rsup Prof. Dr. R. D. Kandou Manado. e-Journal Keperawatan (e-Kp), 4(2), 1-8.

Mulyati, L., Rachman, D., \& Herdiana, Y. (2016). Fakor Determinan Yang Memengaruhi Budaya Keselamatan Pasien Di RS Pemerintah Kabupaten Kuningan. Jurnal Keperawatan Padjadjaran, 4(2).

Najihah. (2018). Literature Review : Budaya Keselamatan Pasien dan Insiden Keselamatan Pasien di Rumah Sakit. Journal of Islamic Nursing, 3(1), 1-8.

Riskiyah. (2018). Pengetahuan Perawat Ruang Rawat Inap tentang Penerapan Sasaran Keselamatan Pasien. Journal of Islamic Medicine. 2 (4). 14-25.

Salawati, Liza. (2020). Penerapan Keselamatan Pasien Rumah Sakit. Jurnal Averrous, 6(1), 98-107.

Simamora, R. H. (2019). Buku ajar pelaksanaan identifikasi pasien. Uwais Inspirasi Indonesia.

Triwibowo, Cecep, dan S. Y. (2016). Handover Sebagai Upaya Peningkatan Keselamatan Pasien. Jurnal Keperawatan Soedirman, 11(2), 76-80. 